\title{
Functional and Phenotypic Characteristics of Effusion-Associated Lymphoid Gells Gultured in the Presence of Either Recombinant Interleukin 2 or T-Cell Growth Factor from Malignant Pleural and Peritoneal Effusions in Patients with Advanced Carcinoma
}

\author{
Tsugio Ebihara and Shohei Koyama \\ Department of Internal Medicine, Institute of Clinical \\ Medicine, University of Tsukuba, Tsukuba 305
}

\begin{abstract}
Ebihara, T. and Koyama, S. Functional and Phenotypic Characteristics of Effusion-Associated Lymphoid Cells Cultured in the Presence of Either Recombinant Interleukin 2 or T-Cell Growth Factor from Malignant Pleural and Peritoneal Effusions in Patients with Advanced Carcinoma. Tohoku J. Exp. Med., 1990, 162 (1), 49-63 - Malignant pleural or peritoneal effusion-associated lymphoid (EAL) cells from 17 patients with advanced carcinoma were cultured with autologous carcinoma cells in the presence of either recombinant interleukin 2 (rIL 2) or T-cell growth factor (TCGF). Considerable cytolytic activity of the cells against allogeneic tumor cells, such as K562 and Daudi cells was induced by the cultivation. TCGF-activated EAL cells acquired higher anti-Daudi tumor cytotoxicity than rIL 2-activated EAL cells. The resultant TCGF-activiated EAL cells from cancer patients significantly exceeded lytic activity of TCGFactivated EAL cells from patients with liver cirrhosis for control $(p<0.01)$. Four of 6 cases examined also showed cytotoxic activity against autologous tumor. In facts, viable carcinoma cells co-cultured with EAL cells and TCGF mostly disappeard during 14 days. Similar phenomenon was not observed in rIL 2activated EAL cells. Thus, it was suggested that more additional lymphokine other than IL 2 was necessary to generate cytotoxic activity against autologous tumor cells. The cell populations responsible for cytolytic activity to allogeneic and/or autologous tumor cells were investigated by two-color flow cytometry. The majority of killer-effector cells against allogeneic cells in rIL 2-activated EAL cells from cancer patients showed $\mathrm{CD} 4^{+} \mathrm{Leu} 8^{-}$phenotype at population level. In contrast, it was suggested that cytolytic activity against allogeneic and/or autologous tumor cells in TCGF-activated EAL cells might be mediated by $\mathrm{CD}^{+}$ $\mathrm{CD} 11^{-}$and $\mathrm{CD} 8^{+} \mathrm{CD} 28^{+}$effector cells. rIL 2; TCGF ; malignant ascites ; LAK ; CTL
\end{abstract}

Received June 28, 1990 ; revision accepted for publication August 20, 1990.

Offprints request: S. Koyama, Department of Internal Medicine, Institute of Clinical Medicine, University of Tsukuba, Tsukuba-City 305, Japan. 
Lymphokine-activated killer (LAK) cells are a group of interleukin 2 (IL 2)-activated cytotoxic cells capable of killing natural killer (NK)-resistant fresh autologous and allogeneic tumor targets in a MHC-unrestricted manner (Grimm et al. 1982 ; Rosenberg and Lotze 1986 ; Koyama et al. 1989b). LAK precursors exist in almost all lymphoid organs (Grimm 1986). Furthermore, LAK cells can be easily generated and expanded in vitro and also have an ability to kill a broad spectrum of tumor targets. Therefore, much attension has been paid to clinical trials of adoptive immunotherapy with LAK cells for treatment of cancer (Rosenberg et al. 1985). However, most LAK cells have low cytotoxicity against autologous tumors (Koyama et al. 1988). On the other hand, tumor-infiltrating lymphocytes (TILs) are now attracting much attension, because they may contain a specific anti-tumor effector cell population. Many human tumors are infiltrated by lymphocytes but it is not understood whether autologous tumor specific cytotoxic T lymphocytes (CTL) exist in the TIL population. Recently, more specific or effective effector cells against autologous tumor cells were obtained from TILs in some tumors (Itoh et al. 1986; Heo et al. 1987; Muul et al. 1987; Belldegrum et al. 1988; Alexander et al. 1990). In addition, Alexander et al. (1990) reported that restimulation of TILs with autologous tumor preferentially induced proliferation of TILs having lytic activity for autologous tumor.

In this study, we used lymphocytes infiltrating the pleural or peritoneal cavity of patients with advanced carcinoma, since malignant pleural or peritoneal effusion presents environments where both effector lymphocytes and tumor target cells coexist in a defined space. This work therefore attempts to examine and characterize effusion-associated lymphoid (EAL) cells restimulated with autologous tumor from patients with advanced carcinoma, particularly in response to recombinant IL 2 (rIL 2) or T-cell growth factor (TCGF), against allogeneic and/or autologous tumor cells.

\section{Materials and Method}

\section{Patients}

Pleural effusions were collected from 6 diagnosed patients with advanced cancer of lung (3), stomach (2) and pancreas (1). The patients ranged in age from 53 to 79 years (mean 68.5 years). Peritoneal effusions (ascites) were collected from 11 diagnosed patients with advanced gastric (9), gallbladder and ovarian carcinoma. The patients ranged in age from 39 to 71 years (mean 59.8 years). Ascites for control group was obtained from 7 patients with liver cirrhosis (48 to 58 years; mean 53.0 years).

\section{Preparation of effusion-associated lymphoid cells}

Pleural and peritoneal effusions $(200-500 \mathrm{ml})$ were collected by paracentesis from patients. The EAL cells were isolated by standard Ficoll-Hypaque (Pharmacia Fine Chemicals, Uppsala, Sweden) density gradient centrifugation (Böyum 1968). The cells obtained from malignant pleural or peritoneal effusions were a mixture of the EAL and viable carcinoma cells. 


\section{Cultivation of EAL cells with rIL 2 or TCGF}

rIL 2 donated by Shionogi Co. Ltd., Osaka, was used at a concentration of $100 \mathrm{U} / \mathrm{ml}$. The culture supernatant from human spleen cells stimulated with $0.08 \%$ phytohemagglutinin (PHP-P ; Difco, Detroit, MI, USA) was used as a source of TCGF at a $50 \%$ final concentration, corresponding to approximately $100 \mathrm{U} / \mathrm{ml}$ as determined by utilizing as the standard IL 2 (Gillis et al. 1978). The detail concerning TCGF preparation was presented in a previous paper (Ebihara et al. 1989 ; Koyama et al. 1989b). Approximately, $2 \times 10^{6}$ EAL cells mixed with autologous carcinoma cells were placed in tissue culture flasks (Falcon 3013, Becton Dickinson and Company, NJ, USA). Namely, the cultivation of the EAL cells was initiated by a mixture of coexisting viable tumor cells. The EAL cells and tumor cells ratios were approximately $100: 1$ to $20: 1$. The tumor cells were judged by morphological examination of Papanicolaou's staining and/or Wright-Giemsa-stained smears. RPMI-1640 medium supplemented with 10\% FCS, $100 \mu \mathrm{g} / \mathrm{ml} \mathrm{kanamycin,} \mathrm{and} \mathrm{50 \%} \mathrm{TCGF}$ preparations or rIL 2. All cultures were maintained for 14 days in $5 \% \mathrm{CO}_{2}$ in air at $37^{\circ} \mathrm{C}$ and fed three times per week by changing the culture medium. At the end of cultivation, tumor cell number in culture flasks was judged by the following criteria: - , No tumor cells ; + , number of tumor cells being small as compared with that at initial cultivation; \#, tumor cells having grown to increase; $\#$, tumor cells being predominat.

\section{Monoclonal antibodies and two-color flow cytometric analysis}

Fluorescein isothiocyanate (FITC)-conjugated anti Leu2a (CD8), anti Leu3a (CD4), anti HLA-DR and anti Leu7 (CD57), and phycoerythrin (PE)-conjugated anti Leu15 (CD11), anti Leu8, anti Leu2a (CD8), anti Leu11 (CD16) and anti IL 2R (CD25) were provided by Becton Dickinson (Mountain View, CA, USA). KOLT 2 (CD28) was obtained from Nichirei Co. Ltd. (Tokyo). Secondary antibody staining was with the PE-conjugated goat anti-mouse IgG antibody (Biomeda Corp., Foster City, CA, USA). Freshly prepared EAL cells or rIL 2-or TCGF-activated EAL cells were stained with fluorochrome-conjugated monoclonal antibody for $30 \mathrm{~min}$ at $4^{\circ} \mathrm{C}$ and were washed twice, as described previously (Ebihara et al. 1989; Koyama et al. 1989b). The cells stained with FITC- and PEconjugated antibodies were analyzed for double labeling by flow cytometry (FACScan analyzer, Becton Dickinson).

\section{Assay for killer cell activities}

Killer cell activities of cell populations were tested against human NK-sensitive K562 and NK-resistant Daudi cells. The cell lines were kindly supplied by Japanese Cancer Researches Bank, National Institute of Hygienic Science, Tokyo. Cultivated autologous tumor cells from cancer patients were used as a target in some cases for cytotoxicity assays. Four million target tumor cells were incubated with $100 \mu \mathrm{Ci}$ of $\mathrm{Na}_{2}{ }^{51} \mathrm{CrO}_{4}$ (Japan Atomic Energy Research Institute, Tokai, Ibaraki) for $120 \mathrm{~min}$ at $37^{\circ} \mathrm{C}$ with occasional gentle shaking. The cells were washed three times with Hanks' solution and finally resuspended in RPMI-1640 medium supplemented with $10 \% \quad$ FCS and $20 \mathrm{mM} \mathrm{N}$-2hydroxyethylpiperagine-N'-2-ethanesulfonic acid (HEPES) (Wako Pure Chemical Industries Ltd., Osaka). The rIL 2- or TCGF-induced cytolytic effects of cultured lymphoid cells on K562 or Daudi cells were examined using a standard 4 -hr ${ }^{51} \mathrm{Cr}$-release assay. A 8-hr ${ }^{51} \mathrm{Cr}$-release assay was performed by the use of effusion carcinoma cells for autologous tumor target and gastric carcinoma cell line, SC-1 (Koyama et al. 1987) for allogeneic tumor target. The labeled target cells $\left(1.5 \times 10^{4}\right)$ was mixed effector cell at 3 effector cell ratios $(\mathrm{T} / \mathrm{E}$ ratios) of $1: 5,1: 10,1: 20$ were and distributed to each well in a final volume of $200 \mu \mathrm{l}$ on round-bottomed microtitter plates (Corning Glass Works, No. 25850 ; Corning, NY, USA) in quadruplicate. After incubation, the plates were centrifuged and cytolysis was evaluated by counting $0.1 \mathrm{ml}$ of supernatant in a gamma-counter. Specific lysis was expressed according to the following 
formula : $\%$ specific lysis $=$ $\frac{\text { experimental release }- \text { spontaneous release }}{\text { maximum release }- \text { spontaneous release }} \times 100$

The maximum releasable counts were determined by repeated freezing and thawing of the labeled cells, and amounted to $80-90 \%$ of the total radioactivity incorporated into the cells. Spontaneous release determined from K562, Daudi and SC-1 target cells incubated in the culture medium was always $5 \%$ or less of the maximum release. However, spontaneous release of labeled autologous carcinoma cells never exceeded $20 \%$ of maximum release in 8 hr.

\section{Statistical analysis}

The data are expressed as mean \pm s.E. The statistical significances of the differences were analyzed by using Student's $t$-test.

\section{Results}

EAL cells from patients with liver cirrhosis or with advanced carcinoma were cultured in the presence of rIL 2 or TCGF for 14 days. The cells from cancer

TABLE 1. Outcome of tumor cells cultured with autologous EAL cells in the presence of rIL 2 or TCGF

\begin{tabular}{|c|c|c|c|c|c|c|c|}
\hline \multirow{2}{*}{\multicolumn{2}{|c|}{ Cases }} & \multirow{2}{*}{$\begin{array}{c}\text { Age } \\
\text { (year) }\end{array}$} & \multirow[t]{2}{*}{ Sex } & \multirow{2}{*}{$\begin{array}{l}\text { Tumor } \\
\text { origin }\end{array}$} & \multirow{2}{*}{$\begin{array}{l}\text { Type of } \\
\text { carcinoma }\end{array}$} & \multicolumn{2}{|c|}{$\begin{array}{l}\text { Outcome of tumor cells } \\
\text { cultured in the } \\
\text { presence of }\end{array}$} \\
\hline & & & & & & rIL 2 & TCGF \\
\hline 1 & T.T. & 79 & $\mathrm{M}$ & $S$ & Adeno & + & - \\
\hline 2 & S.M. & 72 & $\mathrm{~F}$ & S & Adeno & H & - \\
\hline 3 & Y.F. & 67 & M & $\mathrm{L}$ & Adeno & \# & - \\
\hline 4 & T.F. & 67 & $\mathrm{~F}$ & $\mathrm{~L}$ & Adeno & \# & - \\
\hline 5 & Y.Y. & 73 & M & $\mathrm{L}$ & Small cell & \# & + \\
\hline 6 & M.S. & 53 & M & $\mathrm{P}$ & Adeno & + & - \\
\hline 7 & Y.Y. & 39 & $\mathrm{~F}$ & $\mathrm{~S}$ & Adeno & H & - \\
\hline 8 & M.M. & 71 & F & $\mathrm{S}$ & Adeno & \# & - \\
\hline 9 & C.A. & 67 & M & G & Adeno & m & - \\
\hline 10 & T.F. & 67 & $\mathrm{~F}$ & S & Adeno & H & + \\
\hline 11 & A.T. & 59 & M & $\mathrm{S}$ & Adeno & H & + \\
\hline 12 & T.A. & 60 & $\mathrm{~F}$ & $\mathrm{~S}$ & Adeno & \# & - \\
\hline 13 & K.Y. & 71 & M & $\mathrm{S}$ & Adeno & H & + \\
\hline 14 & T.I. & 70 & $\mathrm{~F}$ & S & Adeno & H & + \\
\hline 15 & A.M. & 43 & $\mathrm{~F}$ & $\mathrm{~S}$ & Adeno & - & - \\
\hline 16 & N.N. & 41 & $\mathrm{~F}$ & 0 & Adeno & H & - \\
\hline 17 & K.S. & 70 & $\mathrm{~F}$ & $\mathrm{~S}$ & Adeno & + & - \\
\hline
\end{tabular}

S, stomach; L, lung; $\mathrm{P}$, pancreas ; G, gallbladder ; $\mathrm{O}$, ovary. -, no tumor cells ; + , number of tumor cells being small as compared with that at initial cultivation; H, tumor cells having grown to increase; $\#$, tumor cells being predominant.

Case No. 1-6, Pleural effusion; Case No. 7-16, Peritoneal effusion. 
patients for the cultivation contained the lymphoid cells together with viable tumor cells. The EAL cells generally grew well in respone to autologous tumor in the presence of either rIL 2 or TCGF. TCGF induced better proliferative response of the EAL cells than rIL 2. In some cases, rIL 2-activated EAL cells did not grow at all under the conditions in which tumor cells were predominant. As shown in Table 1, by day 14, in most cases (13 out of 17 cases) tumor cells containing the EAL cells cultured in the presence of rIL 2 developed to increase. By contrast, in most cases tumor cells in the EAL cells (12 of 17 cases) cultivated in the presence of TCGF became not to be viable and disappeared. In only 5 of 17 cases, tumor cells decreased or remained in smaller number.

As shown in Table 2, all of the rIL 2- or TCGF-activated EAL cells tested demonstrated a dose-dependent cytolytic activity against allogeneic tumor cells such as K562 and Daudi cells. rIL 2-activated EAL cells from carcinomatous pleural or peritoneal effusions revealed lower cytotoxic activity than those from ascites from liver cirrhosis for control. However, when the lytic potential was compared between TCGF-activated EAL cells from cancer patients and those from liver cirrhosis without carcinoma, a significant higher difference in cytolysis was seen only against Daudi target cells $(p<0.01)$. Furthermore, the TCGFactivated EAL cells revealed higher cytotoxic activity against Daudi cells, than rIL 2-activated EAL cells in cancer patients.

TABLE 2. Cytolytic activities of EAL cells against allogeneic target cells cultured in the presence of $r I L 2$ or $T C G F$

\begin{tabular}{|c|c|c|c|c|c|c|}
\hline \multirow{2}{*}{ Subjects } & \multirow{2}{*}{$\begin{array}{c}\text { Number of } \\
\text { cases }\end{array}$} & \multirow{2}{*}{$\begin{array}{l}\text { EAL cells } \\
\text { cultured in } \\
\text { the presence of }\end{array}$} & \multirow{2}{*}{ Target } & \multicolumn{3}{|c|}{$\%$ of specific ${ }^{51} \mathrm{Cr}$ release } \\
\hline & & & & $1: 5^{\mathrm{a}}$ & $1: 10^{\mathrm{a}}$ & $1: 20^{\mathrm{a}}$ \\
\hline \multirow{4}{*}{$\begin{array}{l}\text { Ascitis } \\
\text { (Liver } \\
\text { cirrhosis) }\end{array}$} & \multirow{4}{*}{7} & rIL 2 & K562 & - & $32.3 \pm 4.4$ & - \\
\hline & & & Daudi & - & $20.1 \pm 4.1$ & - \\
\hline & & TCGF & K562 & - & $24.8 \pm 1.9$ & - \\
\hline & & & Daudi & - & $11.4 \pm 2.7^{* *}$ & - \\
\hline \multirow{4}{*}{$\begin{array}{l}\text { Cancerous } \\
\text { pleural } \\
\text { effusion }\end{array}$} & \multirow{4}{*}{6} & rIL 2 & K562 & $24.4 \pm 5.7$ & $29.8 \pm 4.7$ & - \\
\hline & & & Daudi & $12.7 \pm 5.3$ & $17.4 \pm 5.1$ & $27.0 \pm 7.1$ \\
\hline & & TCGF & K562 & $28.2 \pm 3.9$ & $29.8 \pm 4.7$ & - \\
\hline & & & Daudi & $21.5 \pm 3.8$ & $28.2 \pm 3.9$ & $36.1 \pm 2.6$ \\
\hline \multirow{4}{*}{$\begin{array}{l}\text { Cancererous } \\
\text { peritoneal } \\
\text { effusion }\end{array}$} & \multirow{4}{*}{11} & rIL 2 & K562 & $25.7 \pm 3.8$ & $33.3 \pm 2.2$ & - \\
\hline & & & Daudi & $12.6 \pm 2.4$ & $16.5 \pm 2.2$ & $21.2 \pm 2.7$ \\
\hline & & TCGF & $\mathrm{K} 562$ & $22.3 \pm 3.5$ & $31.2 \pm 2.5$ & - \\
\hline & & & Daudi & $16.7 \pm 3.7$ & $23.7 \pm 2.9$ & $27.8 \pm 6.2$ \\
\hline
\end{tabular}

aTarget: effector cell ratio.

Values are mean \pm s.E. of number of cases. patients.

${ }^{* *} p<0.01$ against corresponding values for TCGF-activated EAL cells from cancer 
TABLE 3. Cytolytic activities of TCGF-activated EAL cells from cancer patients against autologous tumor cells and allogeneic SC-1 tumor cells

\begin{tabular}{|c|c|c|c|c|c|c|c|c|c|}
\hline \multirow{3}{*}{ Cases } & \multirow{3}{*}{$\begin{array}{c}\text { Age } \\
\text { (year) }\end{array}$} & \multirow{3}{*}{ Sex } & \multirow{3}{*}{$\begin{array}{l}\text { Tumor } \\
\text { origin }\end{array}$} & \multicolumn{3}{|c|}{ Autologous tumor target } & \multicolumn{3}{|c|}{ SC-1 tumor target } \\
\hline & & & & \multicolumn{3}{|c|}{$\%$ of specific ${ }^{51} \mathrm{Cr}$ release } & \multicolumn{3}{|c|}{$\%$ of specific ${ }^{51} \mathrm{Cr}$ release } \\
\hline & & & & $1: 5^{\mathrm{a}}$ & $1: 10^{\mathrm{a}}$ & $1: 20^{\mathrm{a}}$ & $1: 5^{\mathrm{a}}$ & $1: 10^{\mathrm{a}}$ & $1: 20^{\mathrm{a}}$ \\
\hline 1 M.S. & 53 & M & $\mathrm{P}$ & $28.7 \pm 0.7$ & $37.4 \pm 4.0$ & $44.6 \pm 1.0$ & $10.5 \pm 0.7$ & $13.3 \pm 0.3$ & - \\
\hline 2 C.A. & 67 & M & G & - & $36.6 \pm 0.5$ & - & - & - & - \\
\hline 3 T.A. & 60 & $\mathrm{~F}$ & $\mathrm{~S}$ & $3.9 \pm 0.2$ & $10.3 \pm 0.2$ & $20.0 \pm 0.2$ & $6.3 \pm 0.3$ & $13.5 \pm 0.9$ & $23.1 \pm 0.4$ \\
\hline 4 A.M. & 43 & $\mathrm{~F}$ & $\mathrm{~S}$ & $5.9 \pm 0.4$ & $14.9 \pm 5.0$ & $18.6 \pm 4.2$ & $3.0 \pm 0.5$ & $7.6 \pm 1.2$ & $17.4 \pm 2.2$ \\
\hline 5 T.I. & 70 & $\mathrm{~F}$ & $\mathrm{~S}$ & $1.8 \pm 1.0$ & $3.6 \pm 1.1$ & - & $5.6 \pm 0.7$ & $5.6 \pm 1.2$ & - \\
\hline 6 T.F. & 67 & $\mathrm{~F}$ & S & $3.8 \pm 0.3$ & $10.4 \pm 0.4$ & - & $25.7 \pm 0.7$ & $34.6 \pm 0.4$ & - \\
\hline
\end{tabular}

Case No. 1, Pleural effusion; Case No. 2-6, Peritoneal effusion.

$\mathrm{P}$, pancreas ; $\mathrm{G}$, gallbladder; $\mathrm{S}$, stomach.

aTarget cell : effector cell ratio.

Values are mean \pm s.E. of quadruplicate culture.

To test the further efficacy of the restimulation of EAL cells with autologous tumor and TCGF, we tested stimulated effector cells against autologous tumor cells. The results of this experiment are presented in Table 3. The levels of cytotoxicity expressed by TCGF-activated EAL cells were variable, but Case 1, 2, 3 and 4 showed appreciable levels of killing to autologous tumor. TCGFactivated EAL cells also lysed allogeneic SC-1 tumor cells. The lytic response induced by restimulation experiment with autologous tumor and TCGF was not limited to autologous tumor. Nevertheless, the fact may support the disappearance of viable tumor cells co-cultured with pleural or peritoneal EAL cells in the presence of TCGF (Table 1).

To investigate the phenotypic characteristics of the killer cell population, the rIL 2- and TCGF-activated EAL cells were analyzed by two-color immunofluorescence and flow cytometry. Table 4 shows the percentage of two-color fluorescent EAL cells, rIL 2- and TCGF-activated EAL cells reacting with monoclonal antibodies labeled with distinct fluorochromes in controls and patients with advanced carcinomas. Culture of EAL cells in the presence of rIL 2 did not increase the percentage of $\mathrm{CD}^{+} \mathrm{CD}^{+} 1^{-}$cells in both control and experimenal groups. However, the percentage of $\mathrm{CD}^{+} \mathrm{CD}^{-} 1^{-}$cells in TCGF-activated EAL cells derived from cancer patients was shown to be significantly increased as compared with those of EAL cells and rIL 2-activated EAL cells from each experimental group $(56.3 \pm 4.8$, vs. $17.6 \pm 1.7,18.5 \pm 3.9$; and $49.6 \pm 6.5$, vs. $22.1 \pm$ $2.6,19.6 \pm 3.5, p<0.01)$. Thus, $\mathrm{CD}^{+} \mathrm{CD} 11^{-} \mathrm{T}$ lymphocytes were the major expanding cell population in most TCGF-activated EAL cells. While, the percentage of $\mathrm{CD}^{+} \mathrm{CD} 11^{-}$cells was not increased by cultivation of EAL cells in the presence TCGF in control group. The percentage of $\mathrm{CD}^{+}$cells also co- 


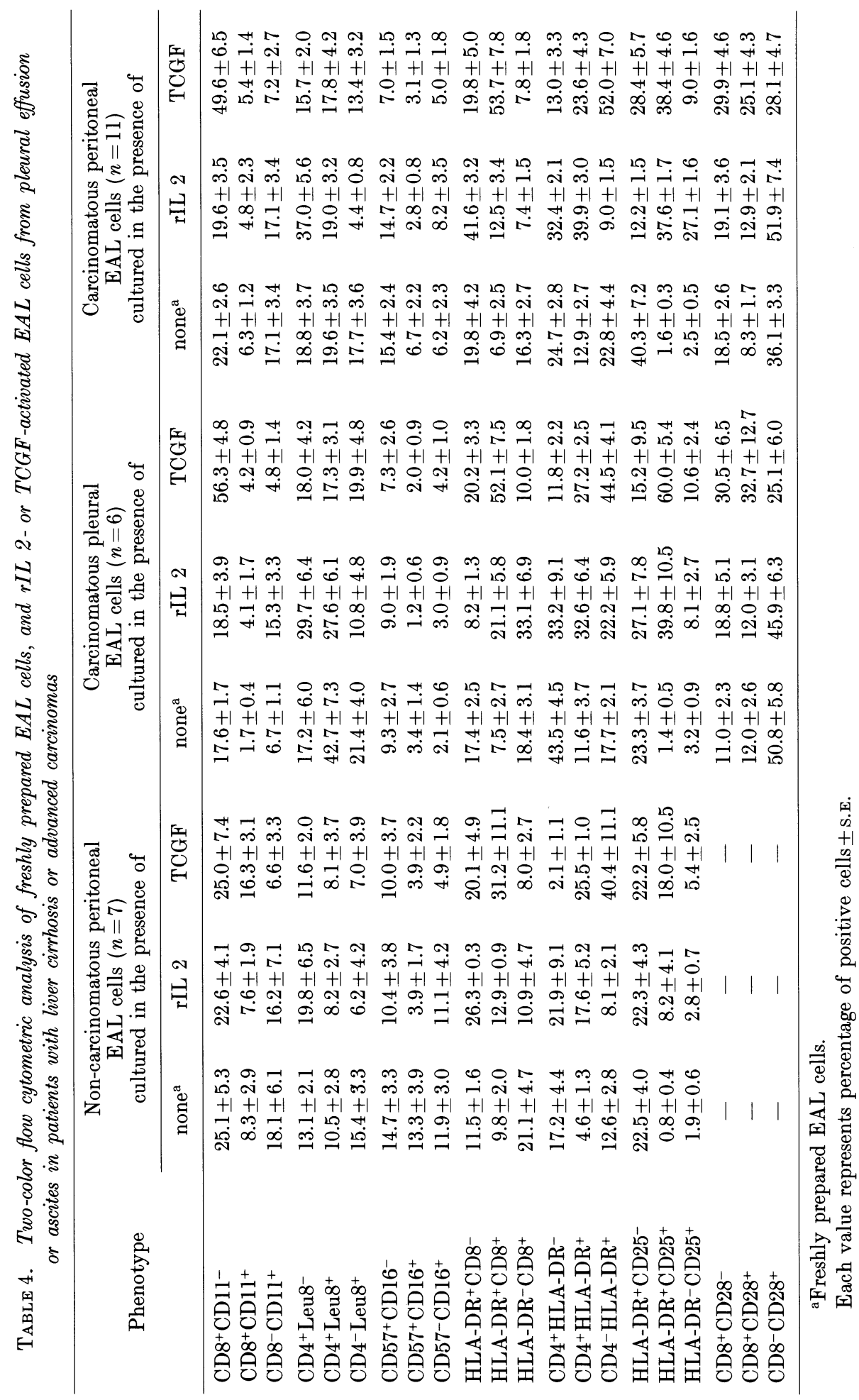


expressing the $\mathrm{CD} 11^{+}$antigen was neither significantly increased nor decreased by culture in the presence of rIL 2 or TCGF. The percentage of CD4 $4^{+}$Leu $8^{-}$cells in experimental groups was significantly increased by culture in the presence of rIL $2(p<0.05)$. However, TCGF neither increased nor decreased the percentage of $\mathrm{CD} 4^{+}$Leu $8^{-}$cells in cancer patients. The percentage of $\mathrm{CD}^{+} \mathrm{Leu} 8^{+}$cells in
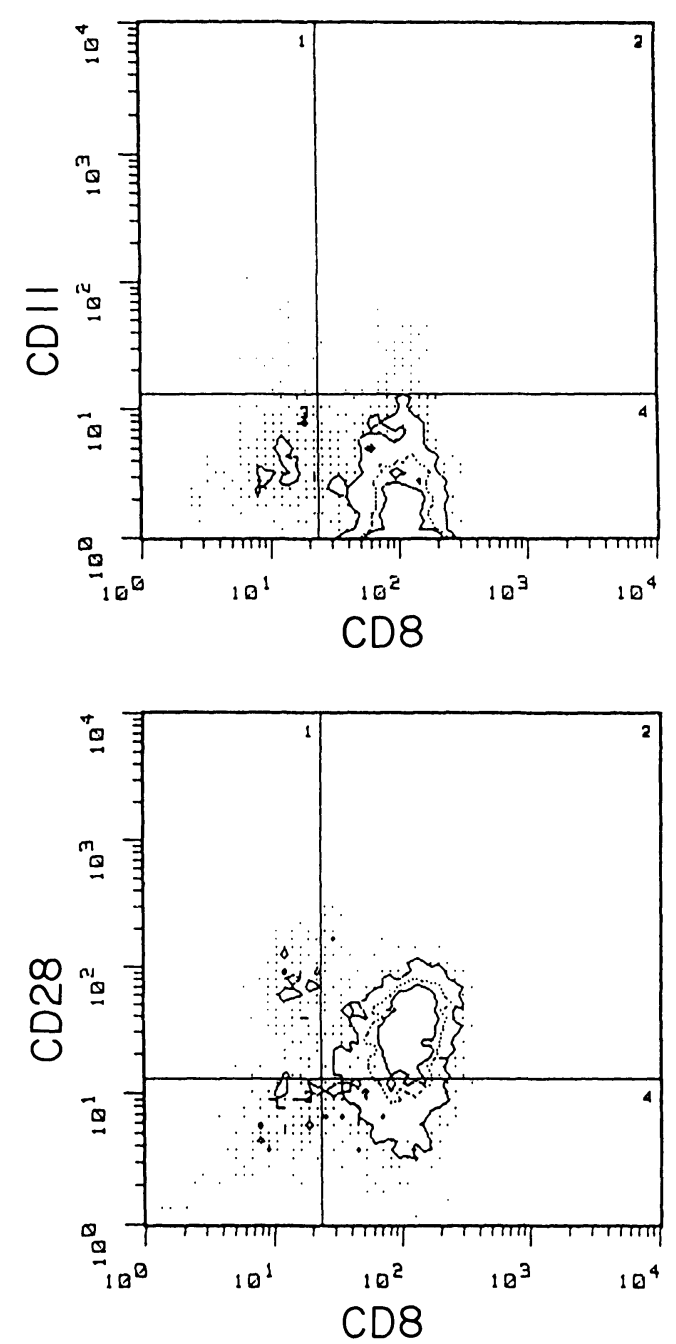

Fig. 1. Representative FACS profiles of cell surface CD8 and CD11, and CD8 and CD28 expression in TCGF-activated EAL cells with cytolytic activity against autologous tumor cells. The results are shown as contuors of green ( $\mathrm{x}$ axis) and orange (y axis) fluorescence. Integration of the four subsets indicates as follows. $\mathrm{CD}^{+}{ }^{+} \mathrm{CD} 11^{-}, \quad 84.1 \%$; $\mathrm{CD}^{+}{ }^{+} \mathrm{CD} 11^{+}, \quad 3.5 \%$; $\mathrm{CD}^{-} \mathrm{CD}_{11}+, \quad 2.5 \%$; $\mathrm{CD}^{-} \mathrm{CD} 11^{-}, 9.9 \%$; $\mathrm{CD}^{+} \mathrm{CD} 28^{-}, 18.0 \%$; $\mathrm{CD}^{+}{ }^{+} \mathrm{CD} 28^{+}, 68.4 \%$; $\mathrm{CD} 8{ }^{-} \mathrm{CD} 28^{+}$, $7.7 \%$; CD8-CD28-, $5.8 \%$. Note the markedly increased proportion of CD8 ${ }^{+}$ $\mathrm{CD}^{-}$and $\mathrm{CD}^{+}{ }^{+} \mathrm{CD} 28^{+}$cells. 
control and experimental groups decreased or remained unchanged under the cultivation in the presence of $\mathrm{rIL} 2$ or TCGF. The percentage of $\mathrm{CD} 57^{+} \mathrm{CD} 16^{-}$, $\mathrm{CD} 7^{+} \mathrm{CDl}^{+}$and $\mathrm{CD}^{+} 7^{-} \mathrm{CDl} 6^{+}$cells in control and experimental groups was decreased or unchanged by the cultivation in the presence of rIL 2 or TCGF. The results of FACS analysis of EAL, rIL 2- or TCGF-activated EAL cells from control and experimental group using anti HLA-DR, and CD8, CD4 or CD25 are shown in Table 4. The most prominent feature is the increased proportion of double-positive cells in rIL 2- and TCGF-activated EAL cells. In addition, we further examined the phenotypic analysis of EAL cells, rIL 2- or TCGF-activated EAL cells defined by CD8 and CD28 in cancer patients. The percentage of CD8 ${ }^{+}$ $\mathrm{CD}^{-} 8^{-}$and $\mathrm{CD} 8^{+} \mathrm{CD} 28^{+}$cells was unchanged or decreased by the cultivation in the presence of rIL 2. However, TCGF preferentially increased the CD8 ${ }^{+} \mathrm{CD} 11^{-}$ and $\mathrm{CD}^{+}{ }^{+} \mathrm{CD} 28^{+}$cells.

Fig. 1 shows an example of a FACS profiles defined by CD8 and CD11, and CD8 and CD28 on TCGF-activated EAL cells with lytic activity against autologous tumor cells from patient with gastric carcinoma (Patient 4 in Table 4). Major expanding cell population revealed $\mathrm{CD} 8^{+} \mathrm{CD} 11^{-}$and $\mathrm{CD} 8^{+} \mathrm{CD} 28^{+}$cells. Talbe 5 shows a summary of the phenotypic characterization of TCGF-activated EAL cells with cytolytic activity against autologous tumor cells. The data were

TABLE 5. Two-color flow cytometric analysis of TCGF-activated EAL cells with cytolytic activities against autologous tumor from pleural or peritoneal effusions

\begin{tabular}{|c|c|c|}
\hline \multirow{2}{*}{ Phenotype } & \multicolumn{2}{|c|}{$\begin{array}{l}\text { Carcinomatous pleural or peritoneal } \\
\text { EAL cells }(n=4) \text { cultured in the presence of }\end{array}$} \\
\hline & None $^{a}$ & TCGF \\
\hline $\mathrm{CD}^{+} \mathrm{CD}^{-} 1^{-}$ & $15.6 \pm 0.3$ & $56.2 \pm 9.6$ \\
\hline $\mathrm{CD}^{+} \mathrm{CD}^{-} 1^{+}$ & $3.8 \pm 0.6$ & $6.2 \pm 1.2$ \\
\hline $\mathrm{CD}^{-}{ }^{-} \mathrm{CD} 11^{+}$ & $15.2 \pm 2.4$ & $9.5 \pm 1.4$ \\
\hline $\mathrm{CD}^{+}{ }^{+} \mathrm{Leu}^{-}$ & $12.0 \pm 1.4$ & $12.1 \pm 3.2$ \\
\hline $\mathrm{CD}^{+}{ }^{+} \mathrm{Leu}^{+}$ & $25.8 \pm 2.7$ & $4.9 \pm 1.1$ \\
\hline $\mathrm{CD}^{-}{ }^{-} \mathrm{Leu}^{+}{ }^{+}$ & $21.9 \pm 3.5$ & $15.2 \pm 3.3$ \\
\hline $\mathrm{CD} 7^{+} \mathrm{CD} 16^{-}$ & $9.6 \pm 1.1$ & $4.8 \pm 1.2$ \\
\hline $\mathrm{CD} 7^{+} \mathrm{CD} 16^{+}$ & $2.6 \pm 0.9$ & $2.9 \pm 0.9$ \\
\hline $\mathrm{CD}^{2} 7^{-} \mathrm{CD} 16^{+}$ & $4.4 \pm 0.4$ & $2.2 \pm 0.1$ \\
\hline $\mathrm{CD}^{+}{ }^{+} \mathrm{CD} 28^{-}$ & $8.3 \pm 0.5$ & $21.4 \pm 3.4$ \\
\hline $\mathrm{CD}^{+} \mathrm{CD}^{2} 8^{+}$ & $12.1 \pm 1.8$ & $39.3 \pm 5.4$ \\
\hline $\mathrm{CD}^{-}{ }^{-} \mathrm{CD} 28^{+}$ & $49.9 \pm 6.5$ & $26.7 \pm 5.6$ \\
\hline
\end{tabular}

${ }^{a}$ Freshly prepared EAL cells.

Each value represents percentage of positive cells in terms of mean \pm S.E. 
characterized by markedly increased proportions of $\mathrm{CD} 8^{+} \mathrm{CD} 11^{-}$and $\mathrm{CD} 8^{+} \mathrm{CD} 28^{+}$ cells. It is likely that the expanded $\mathrm{CD} 8^{+} \mathrm{CD} 11^{-}$and $\mathrm{CD} 8^{+} \mathrm{CD} 28^{+}$cells, at least contain the effector cells responsible for observed cytolytic activity.

\section{Discussion}

This study demonstrates that the cultivation of EAL cells mixed with viable autologous carcinoma cells for 14 days in the presence of either rIL 2 or TCGF results in the generation of killer cells which have the unique property of lysing allogeneic tumor cells and/or autologous tumor cells. Augmented killer cell activity of rIL 2-activated EAL cells from cancer patients was related to the elevated percentage of $\mathrm{CD}^{+} \mathrm{Leu} 8^{-}$cells. The $\mathrm{CD} 8^{+} \mathrm{CD} 11^{-}$and $\mathrm{CD} 57^{+} \mathrm{CD} 16^{-}$ cells, known to be killer T cells (Clement et al. 1984) or NK cells (Abo et al. 1983), respectively, were not expanded with the cultivation in the presence of rIL 2 . The findings in the analysis of the population suggested that the majority of the rIL 2-activated killer-effector cells from cancer patients expressed CD4 ${ }^{+}$Leu8 ${ }^{-}$. The fact is essentially accorded with the phenotypic data of rIL 2-activated PBL from cancer patients in view of the expansion of $\mathrm{CD}^{+} \mathrm{Leu} 8^{-}$cells (Koyama et al. $1989 \mathrm{~b})$. However, the results of phenotypic analysis of rIL 2-activated spleen cells from cancer patients described previously (Ebihara et al. 1990) are different from the present results. Namely, it was found that cytolytic activity of rIL 2-activated spleen cells was mostly associated with $\mathrm{CD} 8{ }^{+} \mathrm{CD} 11^{-}$and $\mathrm{CD} 57^{+} \mathrm{CD} 16^{-}$ lymphoid cells. This may reflect in part the fact that the constituents of subsets of lymphoid cells in EAL cells are similar to PBL (Koyama et al. 1989b) but different from spleen cells (Ebihara et al 1990).

Blanchard et al. (1988) separated tumor cells from EAL cells from pleural or peritoneal effusion obtained from ovarian or metastatic breast cancer patients. Then, the EAL cells without tumor cells cultured in the presence of rIL 2 for 34 days were found to lyse autologous fresh tumor cells, as well as NK-resistant allogeneic tumor cells. They reported that the rIL 2-activated EAL cells with cytolytic activity was phenotypically $\mathrm{CD}_{2}^{+}, \mathrm{CD}^{-}, \mathrm{CD}^{-}, \mathrm{CD}^{-} 6^{+}$and LeuM3- by using a negative selection method. The data were quite different from our phenotypic results. As pointed out previously by us (Koyama et al. 1989b), short-term cultivation would not an effective approach for phenotypic analysis, since expected T cells activated rIL 2 might not be fully expanded, and the cells might consist of several subsets of $\mathrm{T}$ lymphocytes and monocytes. Belldegrun et al. (1988) described the phenotypic analysis of rIL 2-expanded TIL in human renal cells cancer. They observed a concomitant increase in the $\mathrm{CD}^{+}$and $\mathrm{CD} 4^{+}$, and a decrease in $\mathrm{CD}^{+}$cells with continued in vitro expansion (up to 50 days). Furthermore, no consistent changes in the percentage of $\mathrm{CD}_{5} 7^{+}, \mathrm{CD} 16^{+}$, and transferrin, and IL2 receptors were noted. These data of phenotype of rIL 2 -activated TIL were similar to that of rIL 2-activated EAL cells from cancer patients presented here. 
On the other hand, in this paper we have shown that killer cell activity was significantly higher in TCGF-activated EAL cells from cancer patients than in TCGF-activated EAL cells from control. It has been demonstrated that CD28 ${ }^{+}$ subset contains cytotoxic T cell effectors (Fast et al. 1981) and cytotoxic T cell precursors (Damle et al. 1983). Indeed, the augmented activity of the cells as related to the increased $\mathrm{CD} 8^{+} \mathrm{CD} 11^{-}$cells as well as $\mathrm{CD} 8^{+} \mathrm{CD} 28^{+}$populations, and to the decreased or unchanged $\mathrm{CD}^{+} \mathrm{Leu} 8^{-}$and/or $\mathrm{CD} 57^{+} \mathrm{CD} 16^{-}$populations. Similar findings were obtained by the phenotypic analysis of TCGF-activiated EAL cells with cytolytic activity against autologous tumor (Fig. 1 and Table 5). Namely, these EAL cells were $\mathrm{T}$ cells, the majority being $\mathrm{CD}^{+} \mathrm{CD}^{-} 1^{-}$and $\mathrm{CD} 8^{+}$ $\mathrm{CD}^{+} 8^{+}$cells. The above data suggested that $\mathrm{CD}^{+} \mathrm{CD} 11^{-}$and $\mathrm{CD} 8^{+} \mathrm{CD} 28^{+}$ populations may have contained effector cells of cytotoxic acitivity against autologous and allogeneic tumor cells in TCGF-expanded cultures of EAL cells from cancer patients. Thus, it is possible that effector cells against autologous and allogeneic tumor cells are the same population. However, this problem remains to be further investigated in detail.

The LAK cell activity of TCGF-activated PBL from cancer patients has been shown to decrease with the progress of tumor invasion, and to be significantly lower than that from normal control (Koyama et al. 1989b). This was a reason that suppressor cells with surface phenotype $\mathrm{CD} 8^{+} \mathrm{CD} 11^{-}$were included among the TCGF-activated PBL from cancer patients (Ebihara et al. 1989). Such an inhibitory effect was not exhibited by TCGF-activated EAL cells, in spite of the presence of increased $\mathrm{CD} 8^{+} \mathrm{CD} 11^{-}$cells after TCGF activation. Thus, it seems possible that TCGF-activated EAL cells do not exert a suppressor effect. On the contrary, it was found that TCGF-activated EAL cells from patients with metastatic advanced carcinoma in the present study showed significnatly higher cytolytic activity against NK-resistant tumor cells than those from liver cirrhosis patients. As stated above in this paper, EAL cells from cancer patients contained viable tumor cells. Vose and Bonnard (1982) and Vánkey and Klein (1982) reported in the induction of autologous tumor specific-cytotoxic lymphocytes by mixed culture of PBL with untreated autologous tumor cells. In such a mixed lymphocytes-tumor cell culture (MLTC) lytic potential to autologous tumor has been generated by many investigators (Vánkey and Klein 1982; Ichino and Ishikawa 1984; Sato et al. 1986; Slingluff et al. 1988; Uchida et al. 1988; Koyama et al. 1989a). In our recent work (Koyama et al. 1989a), we found that mixed cultivation of PBL in the presence of TCGF and mitomycin C (MMC)treated autologous carcinoma cells induced cytotoxic $\mathrm{T}$ lymphocytes (CTL) specific for autologous tumors. In the experiments presented here, cytolytic response to autologous tumor was not specific, since TCGF-activated EAL cells lysed allogeneic SC-1 tumor cells. Our reports differ from those in melanoma (Itoh et al. 1986; Muul et al. 1987; Slingluff et al. 1988) where a portion of the TIL was specific for the autologous tumor. Although tumor-specific CTL from 
other tumor systems have not been well documented, studies have shown that TILs from head and neck cancer (Heo et al. 1987), renal cell carcinoma (Belldegrum et al. 1988 ; Alexander et al. 1990), ovarian cancer (Ferrini et al. 1985; Allavena et al. 1986; Blanchard et al. 1988) and lung cancer (Yano et al. 1989) are not specific for autologous tumor. However, several TILs tested were found to lyse autologous tumor cells (Table 2). In addition, viable tumor cells in EAL cells from most cases disappeared with continued in vitro cultivation in the presence of TCGF up to 14 days (Table 1). These results suggest that restimulation of EAL cells with autologous tumor and TCGF can enhance proliferative response and cytolytic activity against autologous tumor. The resultant cytotoxicity of TCGF-activated EAL cells might thus be a cumulative effect of CTL and LAK cells, perhaps both operative in autologous target cytotoxicity and the latter operative in allogeneic target lysis. The EAL cells from cancer patients seem to harbor precursors for potential effector cell populations against autologous tumor.

However, viable tumor cells in EAL cells cultivated with rIL 2 did not disappear and tended to grow to increase. The fact suggests that specific or effective effector cells against autologous tumor cells in EAL populations might not be induced by the cultivation in the presence of rIL 2. Similar finding (Allavena et al. 1986 ) was obtained from rIL 2-activated EAL cells in patient with advanced ovarian adenocarcinoma. Yano et al. (1989) reported that rIL 2-activated TILs from primary lung cancer tissues had a lower cytolytic activity against autologous tumor. Furthermore, they showed that exogenous addition of IFN $\gamma$ to rIL 2 culture of TILs enhanced cytolytic activity. In the context, we previously reported that TCGF was more useful for the induction of effective CTL against autologous tumor in MLTC reaction as compared with using rIL 2 (Koyama et al. 1989a). Similar enhanced cytotoxic activity induced by TCGF was reported by Ferrini et al. (1985). They revealed that CD8 ${ }^{+} \mathrm{T}$ cell clone capable lysing both allogeneic or autologous tumor cells was obtained from ascitic fluid of patients with ovarian carcinoma. TCGF has been found to contain many kinds of cytokines, such as IL 1, IL 3, IL 4, IL 5, IL 6, IFN $\gamma$ and tumor necrosis factor (TNF) in addition to IL 2 . Indeed, $\mathrm{Li}$ et al. (1989) reported that the cultivation of TIL with TNF $\alpha$ and IL 2 synergized early in culture to induce tumor reactive $\mathrm{CD}^{+}$effectors, some of which might be specific for autologous tumor cells. Thus, culturing of human EAL cells in the presence of TCGF containing these factors might result in their development of antitumor cytotoxicity. Consequently, in order to generate effective effector cells against autologous carcinoma cells, it seems to require additional factors other than IL 2 (Koyama et al. 1989a ; Yano et al. 1989; Ferrini et al. 1985 ; Li et al. 1989). IL 2-expanded EAL cells have been expected to be a therapeutically important source of effectors for adoptive immunotherapy. However, our present study shows that cultivation of EAL cells in the presence of rIL 2 alone appears impossible to give rise to more efficient effector cells against autologous tumor 
cells. Whatever the mechanism(s) of autologous tumor killing, our present study indicates that TCGF-activated EAL cells with cytolytic activity contain effective effector cells at least against autologous tumor cells. Whether the cytolytic EAL cells expanded with TCGF will be useful for adoptive immunotherapy remains to be determined.

\section{Acknowledgments}

This study was supported by Grant-in-Aid for scientific research (No. 62570307) from the Ministry of Education, Science and Culture, Japan, and Osaka Foundation Grant of Research for Cancer.

\section{References}

1) Abo, T., Miller, C.A., Gartland, G.L. \& Balch, C.M. (1983) Differential stages of human natural killer cells in lymphoid tissues from fetal to adult life. J. Exp. Med., 157, 273-284.

2) Alexander, J., Rayman, P., Edinger, M., Connelly, R., Tubbs, R., Bukowski, R., Pontes, E. \& Finke, J. (1990) TIL from renal-cell carcinoma: Restimulation with tumor influences proliferation and cytolytic activity. Int. J. Cancer, 45, 119-124.

3) Allavena, P., Zanaboni, F., Rossini, S., Marendino, A., Bonazzi, C., Vassena, L., Mangioni, C. \& Mantovani, A. (1986) Lymphokine-activated killer activity of tumor-associated and peripheral blood lymphocyted isolated from patients with ascites ovarian tumors. J. Natl. Cancer Inst., 77, 863-868.

4) Belldegrum, A., Muul, L.M. \& Rosenberg, S.A. (1988) Interleukin 2 expanded tumor-infiltrating lymphocytes in human renal cell cancer: Isolation, characterization, and antitumor activity. Cancer Res., 48, 206-214.

5) Blanchard, D.K., Kavanagh, J.J., Sinkovics, J.G., Cavanagh, D., Hewitt, S.M. \& Djeu, J.Y. (1988) Infiltration of interleukin-2 inducible killer cells in ascitic fluid and pleural effusions of advanced cancer patients. Cancer Res., 48, 6321-6327.

6) Böyum, A. (1968) Isolation of mononuclear cells and granulocytes from human blood. Scand. J. Lab. Invest., 21, Suppl. 97, 77-89.

7) Clement, L.T., Dagg, H.D. \& Landy, A. (1984) Characterization of human lymphocyte subpopulations: Alloreactive cytotoxic T-lymphocyte precursor and effector cells are phenotypically distinct from Leu $2^{+}$suppressor cells. J. Clin. Immunol., 4, 395-402.

8) Damle, N.K., Mohagheghpour, N., Hansen, J.A. \& Engleman, E.G. (1983) Alloantigen-specific cytotoxic and suppressor $\mathrm{T}$ lymphocytes are derived from phenotypically distinct precursors. J. Immunol., 131, 2296-2300.

9) Ebihara, T., Koyama, S., Fukao, K. \& Osuga, T. (1989) Lymphokine-activated suppressor (LAS) cells in patients with gastric carcinoma. Cancer Immunol. Immunother., 28, 218-224.

10) Ebihara, T., Fukao, K. \& Koyama, S. (1990) Functional and phenotypic characteristics of recombinant interleukin 2 or T-cell growth factor-activated splenic lymphoid cells from patients with gastric or hepatocellular carcinoma. Cancer, 66, 923-929.

11) Fast, L.D., Hansen, J.A. \& Newman, W. (1981) Evidence for T cell nature and heterogeneity within natural killer $(\mathrm{NK})$ and antibody-dependent cellular cytotoxicity (ADCC) effectors: A comparison with cytolytic T lymphocytes (CTL). J. Immunol., 127, 448-452.

12) Ferrini, S., Biassoni, R., Moretta, A., Bruzzone, M., Nicolin, A. \& Morreta, L. (1985) Clonal analysis of $\mathrm{T}$ lymphocytes isolated from ovarian carcinoma ascitic fluid. Phenotypic and functional characterization of T-cell clones capable of lysing 
autologous carcinoma cells. Int. J. Cancer, 36, 337-343.

13) Gillis, S., Fern, M.M., Ou, W. \& Smith, K.A. (1978) T cell growth factor : Parameters of production and a quantitative microassay for activity. J. Immunol., 120, 2027-2032.

14) Grimm, E.A. (1986) Human lymphokine-activated killer (LAK) cells as a potential immunotherapeutic modality. Biochim. Biophys. Acta, 865, 267-279.

15) Grimm, E.A., Mazunder, A., Zhang, H.Z. \& Rosenberg, S.A. (1982) Lymphokineactivated killer cell phenomenon. Lysis of natural-killer resistant fresh solid tumor by interleukin-2 activated autologous human peripheral blood lymphocytes. $J$. Exp. Med., 155, 1823-1843.

16) Heo, D.S., Whiteside, T.L., Johnson, J.T., Chen, K., Barnes, E.L. \& Herberman, R.B. (1987) Long-term interleukin 2-dependent growth cytotoxic activity of tumorinfiltrating lymphocytes from human squamous cell carcinomas of the head and neck. Cancer Res., 47, 6353-6362.

17) Ichino, Y. \& Ishikawa, T. (1984) Generation of human cytotoxic T lymphocytes against fresh autologous and allogeneic solid tumors by mixed lymphocytes tumor cell culture with T-cell growth factor. Jpn. J. Cancer Res., 75, 436-441.

18) Itoh, K., Tilden, A.B. \& Balch, C.M. (1986) Interleukin 2 activation of cytotoxic T-lymphocytes infiltrating into human metastatic melanomas. Cancer Res., 46, 30113017.

19) Koyama, S., Mukai, R., Fukao, K., Arimura, H., Iwasaki, Y. \& Osuga, T. (1987) Monoclonal antibody against human gallbladder carcinoma-associated antigen. Cancer Res., 47, 4667-4673.

20) Koyama, S., Ebihara, T., Fukao, K. \& Osuga, T. (1988) Analysis of induction of cytotoxic T cells against human cancer cells. Proc. Jpn. Cancer Assoc., 47, 461.

21) Koyama, S., Ebihara, T., Fukao, K. \& Osuga, T. (1989a) Effect of cytokine on the induction of cytotoxic T cells against human autologous tumor cells. Proc. Jpn. Cancer Assoc., 48, 278.

22) Koyama, S., Ebihara, T., Fukao, K. \& Osuga, T. (1989b) Differential activation of lymphokine-activated killer cells with different surface phenotypes by cultivation with recombinant interleukin 2 or T-cell growth factor in gastric cancer patients. Jpn. J. Cancer Res., 80, 150-157.

23) Li, W.Y., Lusheng, S., Kanbour, A., Herberman, R.B. \& Whiteside, T.L. (1989) Lymphocytes infiltrating human ovarian tumors: Synergy between tumor necrosis factor and interleukin 2 in the generation of $\mathrm{CD}^{+}$effectors from tumor-infiltrating lymphocytes. Cancer Res., 49, 5979-5985.

24) Muul, L.M., Spiess, P.J., Director, E.P. \& Rosenberg, S.A. (1987) Identification of specific cytolytic immune responses against autologous tumor in humans bearing malignant melanoma. J. Immunol., 138, 989-995.

25) Rosenberg, S.A. \& Lotze, M.T. (1986) Cancer immunotherapy using interleukin-2 activated lymphocytes. Ann. Rev. Immunol., 4, 681-709.

26) Rosenberg, S.A., Lotze, M.T., Muul, L.M., Leitman, S., Change, A.E., Ettinghausen, S.E., Matory, Y.C., Skibber, J.M., Shiloni, E., Vetto, J.T., Seipp, C.A., Simpson, C. \& Reichert, C.M. (1985) Observation on the systemic administration of autologous lymphokine activated killer cells and recombinant interleukin 2 to patient with metastatic cancer. $\quad$ N. Engl. J. Med., 313, 1485-1492.

27) Sato, T., Sato, N., Takahashi, S., Koshiba, H. \& Kikuchi, K. (1986) Specific cytotoxicity of a long-term cultured T-cell clone on human autologous mammary cancer cells. Cancer Res., 46, 4384-4389.

28) Slingluff, C.L., Darrow, T., Vervaert, C., Quinn-Allen, M.A. \& Seigler, H.F. (1988) Human cytotoxic $\mathrm{T}$ cells specific for autologous melanoma cells : Successive generation from lymph node cells in seven consecutive cases. J. Natl. Cancer Inst., 80, 1016-1026. 
29) Uchida, A., Moore, M. \& Klein, E. (1988) Autologous mixed lymphocyte-tumor reaction and autologous mixed lymphocyte reaction. II. Generation of specific and non-specific killer $\mathrm{T}$ cells capable of lysing autologous tumor. Int. J. Cancer, 41, 651-656.

30) Yano, T., Yasumoto, K., Togami, M., Ishida, T., Kimura, G., Sugimachi, K. \& Nomoto, K. (1989) Properties of recombinant interleukin 2-cultured tumor-infiltrating lymphocytes in human lung cancer. Int. J. Cancer, 43, 619-623.

31) Vánkey, F. \& Klein, E. (1982) Specificity and auto-tumor cytotoxicity exerted by fresh, activated and propergated human T lymphocytes. Int. J. Cancer, 29, 547-553.

32) Vose, B.M. \& Bonnard, G.D. (1982) Human tumor antigens defined by cytotoxicity and proliferative response of cultured lymphoid cells. Nature, 296, 351-361. 